\title{
Active modified atmosphere storage to preserve the quality of 'San Andreas' strawberries harvest at two ripening stages
}

\author{
Jéssica Mayumi Anami ${ }^{1}$, Cristiano André Steffens ${ }^{2}$, Marcelo Alves Moreira ${ }^{2}$, Raquel Carlos Fernandes ${ }^{1}$, \\ Deysi Jhoana Camayo Mosquera ${ }^{1}$, Cassandro Vidal Talamini do Amarante ${ }^{2}$
}

\begin{abstract}
This work was carried out to evaluate the effect of fruit ripening stage at harvest (" $1 / 3$ ripe" and " $3 / 4$ ripe", respectively with $30 \%$ and $75 \%$ of red color) and passive modified atmosphere (MA) and active MA (with initial initial low $\mathrm{O}_{2}$ and/or high $\mathrm{CO}_{2}$ ) on quality of 'San Andreas' strawberries, with emphasis on bioactive compounds and metabolites of fermentative metabolism. The treatments evaluated were: control; passive MA [low density polyethylene (LDPE) packaging of $40 \mu \mathrm{m}$ ]; active MA with initial low $\mathrm{O}_{2}(1 \mathrm{kPa})$; active MA with initial high $\mathrm{CO}_{2}(30 \mathrm{kPa})$; and active $\mathrm{MA}$ with initial low $\mathrm{O}_{2}(1 \mathrm{kPa})$ and high $\mathrm{CO}_{2}(30 \mathrm{kPa})$. After 14 days of storage $\left(0.5 \pm 0.2^{\circ} \mathrm{C} / 92 \pm 2 \% \mathrm{RH}\right)$ followed by two days of shelf life $\left(20 \pm 5^{\circ} \mathrm{C} / 65 \pm 10 \% \mathrm{RH}\right)$, fruit weight loss was higher in control fruit. Soluble solids content and titratable acidity were not different between treatments. Fruit harvested "1/3 ripe" were firmer and had less intense red color after storage than fruit harvested "3/4 ripe". Storage conditions did not affect fruit texture maintenance, but all MA conditions delayed fruit red color evolution, regardless of ripening stage at harvest. Strawberries harvested " $1 / 3$ ripe" and stored in active MA with initial high $\mathrm{CO}_{2}$ had lower incidence and severity of decay. In general, total phenolic compounds (TPC) and total antioxidant activity (TAA) were higher in fruit harvested " $1 / 3$ ripe". The metabolites of the fermentative metabolism were higher in fruit harvested " $3 / 4$ ripe" and stored in active MA with initial low $\mathrm{O}_{2}$. Fruit harvested " $1 / 3$ ripe" had higher values of TPC and TAA and lower incidence of decay after storage. The use of active MA with initial high partial pressure of $\mathrm{CO}_{2}$ preserves the postharvest life of 'San Andreas' strawberries, by reducing decay without increasing the metabolites of the fermentative metabolism.
\end{abstract}

Index terms: Fragaria ananassa, high $\mathrm{CO}_{2}$, low $\mathrm{O}_{2}$, texture, phenolic compounds, fermentative metabolism, decay, fruit quality.

\section{Atmosfera modificada ativa na preservação da qualidade de morangos 'San Andreas' colhidos em dois estádios de amadurecimento}

\begin{abstract}
Corresponding author:
cristiano.steffens@udesc.br
\end{abstract}

Received: June 10, 2019

Accepted: December 11, 2019

Copyright: All the contents of this journal, except where otherwise noted, is licensed under a Creative Commons Attribution License.

\section{(cc) $\mathbf{E Y}$}

Resumo - O objetivo desse trabalho foi avaliar o efeito do estádio de amadurecimento na colheita (" $1 / 3$ maduro" e " $3 / 4$ maduro", frutos com $30 \%$ e $75 \%$ de cor vermelha, respectivamente) e da atmosfera modificada (AM) passiva e ativa (com baixa pressão parcial inicial de $\mathrm{O}_{2} \mathrm{e} / \mathrm{ou}$ alta pressão parcial inicial de $\mathrm{CO}_{2}$ ) sobre a qualidade de morangos 'San Andreas', especialmente sobre compostos bioativos e metabolismo fermentativo. Os tratamentos avaliados foram: controle; AM passiva [embalagem de polietileno de baixa densidade (PEBD) de $40 \mu \mathrm{m}]$; $\mathrm{AM}$ ativa com baixo $\mathrm{O}$ inicial $(1 \mathrm{kPa})$; $\mathrm{AM}$ ativa com alto $\mathrm{CO}_{2}$ inicial $(30 \mathrm{kPa})$; e $\mathrm{AM}$ ativa com baixo $\mathrm{O}_{2}(1 \mathrm{kPa})$ e alto $\mathrm{CO}_{2}(30 \mathrm{kPa})$ iniciais. Após 14 dias de armazenamento $\left(0,5 \pm 0,2{ }^{\circ} \mathrm{C} / 92 \pm 2 \%\right.$ de UR) e mais dois dias em condição ambiente $\left(20 \pm 5^{\circ} \mathrm{C} / 65 \pm 10 \%\right.$ de UR), a perda de peso dos frutos foi maior no tratamento controle. Os sólidos solúveis e a acidez titulável não apresentaram diferenças entre os tratamentos avaliados. Os frutos do estádio "1/3 maduro" apresentaram-se menos vermelhos e mais firmes do que os do estádio "3/4 maduro" após o armazenamento. As condições de armazenamento não influenciaram na manutenção da textura dos frutos, mas todas as condições de AM reduziram a evolução da cor vermelha dos frutos, independentemente do estádio de amadurecimento. Os morangos colhidos no estádio "1/3 maduro" e armazenados em AM ativa com alto $\mathrm{CO}$ inicial apresentaram menores valores de incidência e severidade de podridões. O conteúdo de compostos fenólicos totais (CFT) e a atividade antioxidante total (AAT), de maneira geral, foram maiores nos frutos colhidos no estádio " $1 / 3$ maduro". Os produtos do metabolismo fermentativo foram maiores em frutos colhidos no estádio " $3 / 4$ maduro" e armazenados em AM ativa com baixo $\mathrm{O}_{2}$ inicial. Frutos colhidos no estádio "1/3 maduro" apresentam maiores valores de CFT e AAT e menor incidência de podridões após o armazenamento. A utilização de AM ativa com alta pressão parcial inicial de $\mathrm{CO}_{2}$ preserva a vida pós-colheita de morangos 'San Andreas', pois reduz podridões sem causar incremento nos produtos do metabolismo fermentativo.

Termos para indexação: Fragaria ananassa, alto $\mathrm{CO}_{2}$, baixo $\mathrm{O}_{2}$, textura, compostos fenólicos, metabolismo fermentativo, doenças, qualidade de frutos. 


\section{Introduction}

Strawberry (Fragaria x ananassa) is considered one of the most important fruit in the world, being consumed in natura or in a wide range of processed products. The distribution and commercialization of strawberry in natura at long distances is restrict due to its high perishability, soft texture, high loss of texture and high susceptibility to decay (LU et al., 2018).

Postharvest handling practices, such as cold storage, change of storage atmosphere, physical treatments and fruit treatment with edible coatings can reduce the rate of deterioration and maintain product quality after prolonged storage and during marketing (SIDDIQUI, 2018).

Treatment with high $\mathrm{CO}_{2}$ can improve the storage potential of the fruit by the activation of genes related to the abiotic stress and deactivation of genes associated to the disassembly of cell wall (BANG et al., 2018). Atmospheres with high $\mathrm{CO}_{2}(\geq 15 \mathrm{kPa})$ delay the loss of texture and senescence of the fruit, as well as decay (VAZQUEZ-HERNANDEZ et al., 2018).

There are no studies regarding the antioxidant activity, phenolic content and metabolites of fermentation metabolism at postharvest due to ripening stage at harvest and the use of conservation technologies in 'San Andreas' strawberries produced under Brazilian edaphoclimatic conditions.

This work was carried out to evaluate the effect of fruit ripening stage at harvest and modified atmosphere (MA) condition (passive or active) on quality of 'San Andreas' strawberries, with emphasis on bioactive compounds and metabolites of fermentative metabolism.

\section{Materials and methods}

'San Andreas' strawberries were harvested in two ripening stages (" $1 / 3$ ripe" and " $3 / 4$ ripe", respectively with $30 \%$ and $75 \%$ of red color) in a commercial production area conducted under conventional system, in Lages, SC (27 $48^{\prime} 58^{\prime \prime} \mathrm{S}$ and $50^{\circ} 19^{\prime} 34^{\prime \prime} \mathrm{W}$, altitude of $884 \mathrm{~m}$ ), in June (winter harvest) of 2018.

Fruit were left in polyethylene terephthalate (PET) trays (with capacity for $200 \mathrm{~g}$ ) then covered by a film of polyvinyl chloride (PVC) and packed in corrugated cardboard boxes used for transport and marketing of strawberries. Fruit were then submitted to the following treatments: control; passive MA; active MA with initial low $\mathrm{O}_{2}(1 \mathrm{kPa})$; active MA with initial high $\mathrm{CO}_{2}(30$ $\mathrm{kPa})$; and active $\mathrm{MA}$ with initial low $\mathrm{O}_{2}(1 \mathrm{kPa})$ and high $\mathrm{CO}_{2}(30 \mathrm{kPa})$. Fruit submitted to all MA conditions were packed with a low density polyethylene (LDPE; $40 \mu \mathrm{m}$ ) and then the air was suctioned (until the film molded to the boxes). For treatments with active MA, after the air suction, $\mathrm{N}_{2}$ and/or $\mathrm{CO}_{2}$ were injected (from high pressure cylinders with minimum purity of $99.9 \%$ ) to achieve the partial pressures of $\mathrm{O}_{2}$ and/or $\mathrm{CO}_{2}$ established in each active MA treatment. Fruit of all treatments were cold stored $\left(0.5 \pm 0.2^{\circ} \mathrm{C}\right.$ and $\mathrm{RH}$ of $\left.92 \pm 2 \%\right)$ for 14 days, followed by two days of shelf life $\left(20 \pm 5^{\circ} \mathrm{C}\right.$ and $\left.65 \pm 10 \% \mathrm{RH}\right)$, and then assessed for quality.

The partial pressures of $\mathrm{O}_{2}$ and $\mathrm{CO}_{2}$ inside the packages of MA treatments along the storage period (which changed as a result of respiration of the fruit and film permeability to the gases) were assessed every three days with a gas analyzer (Shelle, Germany).

Fruit were assessed in terms of weight loss, skin color $\left(L, C\right.$ and $h^{\circ}$ ), soluble solids content (SSC), titratable acidity (TA), skin and flesh textures, total phenolic compounds (TPC), total antioxidant activity (TAA) and incidence of decay, according the methodology described by Soethe et al. (2016). Skin and flesh texture were assessed with a texturometer TAXT-Plus ${ }^{\circledR}$, with a PS2 probe (diameter of $2 \mathrm{~mm}$ ) introduced into the flesh at 10 $\mathrm{mm}$ depth. The results were expressed in Newton $(\mathrm{N})$. Fruit were also assessed in terms of severity of decay according the following scale ( $\%$ of fruit with decay): $1=$ $<25 \% ; 2=26-50 \% ; 3=51-75 \%$; and $4=\geq 76 \%$.

The products of fermentative metabolism (acetaldehyde, ethanol and ethyl acetate) were assessed by gaseous chromatography (with a Clarus 580 chromatographer, Perkin Elmer) equipped with a capillary column Elite-wax (Perkin Elmer, with length of $30 \mathrm{~m}$, internal diameter of $0.25 \mathrm{~mm}$ and follicular diameter of $0.25 \mu \mathrm{M}$ ), with nitrogen flow of $1 \mathrm{~mL} \mathrm{~min}^{-1}$, injector and detector temperatures of $180^{\circ} \mathrm{C}$ and $250^{\circ} \mathrm{C}$, respectively, initial temperature of $40^{\circ} \mathrm{C}$ for 2.20 minutes, followed by an increase to $45^{\circ} \mathrm{C}$ for 30 minutes, and then an increase to $70{ }^{\circ} \mathrm{C}$ for 0.10 minutes. Fruit of each treatment had a slice removed at the middle portion and the tissue processed in a centrifuge for juice extraction. Samples of $20 \mathrm{~mL}$ of juice were collected in vials (volume of $40 \mathrm{~mL}$ ) and stored in freezer at $-18^{\circ} \mathrm{C}$ until analysis. Before the analysis in the cromatographer, the samples were defrozeed and left in water bath at $70^{\circ} \mathrm{C}$ for 1 hour. Samples were removed from the water bath, left for 15 minutes (to allow juice droplets to condense leaving only the gas), and four headspace samples were collected from these containers using a 1.0 $\mathrm{mL}$ plastic syringe, following the injection into the gas chromatographer.

The experiment followed a randomized factorial design $(2 \times 5)$, with two ripening stages and five storage conditions, and five replicates of 20 fruit. Percentage values were transformed to arcsine $[(\mathrm{x}+0.5) / 100]^{1 / 2}$ before the statistical analysis. Data were submitted to analysis of variance and treatment means compared by Tukey's test $(\mathrm{p}<0.05)$. 


\section{Results and discussion}

Strawberry 'San Andreas' harvested " $1 / 3$ ripe" had skin color with lightness $(L)$ of 36.4 and $h^{\circ}$ of 38.6, SSC of $6.7^{\circ}$ Brix, TA of $0.24 \%$, SSC/TA ratio of 27.9 , and skin and flesh textures of $2.3 \mathrm{~N}$ and $1.2 \mathrm{~N}$, respectively. Fruit harvested " $3 / 4$ ripe" had skin color with $L$ of 34.8 and $h^{\circ}$ of 36.2 , SSC of $7.5^{\circ}$ Brix, TA of $0.23 \%$, SSC/TA ratio of 32.6, and skin and flesh textures of $1.7 \mathrm{~N}$ and 0.9 $\mathrm{N}$, respectively

Figure 1 shows the partial pressures of $\mathrm{O}_{2}$ and $\mathrm{CO}_{2}$ in the atmosphere for the different treatments along 14 days of storage. Control treatment (without MA) had no substantial changes of $\mathrm{O}_{2}$ and $\mathrm{CO}_{2}$ along the storage period. Passive MA had a reduction of $\mathrm{O}_{2}$, reaching 9.3 $\mathrm{kPa}$ at 9 days of storage, and an increase of $\mathrm{CO}_{2}$, reaching $3.6 \mathrm{kPa}$ at 5 days of storage. Active MA with initial low $\mathrm{O}_{2}(1 \mathrm{kPa})$ had an increase of $\mathrm{O}_{2}$, reaching $11.1 \mathrm{kPa}$ at 12 days of storage, while $\mathrm{CO}_{2}$ increased to $5.0 \mathrm{kPa}$ at 9 days of storage. Active MA with initial high $\mathrm{CO}_{2}(30$ $\mathrm{kPa})$ exhibit a rapid decrease of $\mathrm{CO}_{2}$ until the $5^{\text {th }}$ day of storage $(6.7 \mathrm{kPa})$ and remained almost constant for the remaining period of storage, while $\mathrm{O}_{2}$ decreased to $\sim 8$ $\mathrm{kPa}$ after the $12^{\text {th }}$ day of storage. Active MA with initial low $\mathrm{O}_{2}$ and high $\mathrm{CO}_{2}$ had a reduction of $\mathrm{CO}_{2}$ similar to the treatment of active MA with initial high $\mathrm{CO}_{2}$, while $\mathrm{O}_{2}$ had an increase of $\mathrm{O}_{2}$ similar to the treatment of active MA with initial low $\mathrm{O}_{2}$.

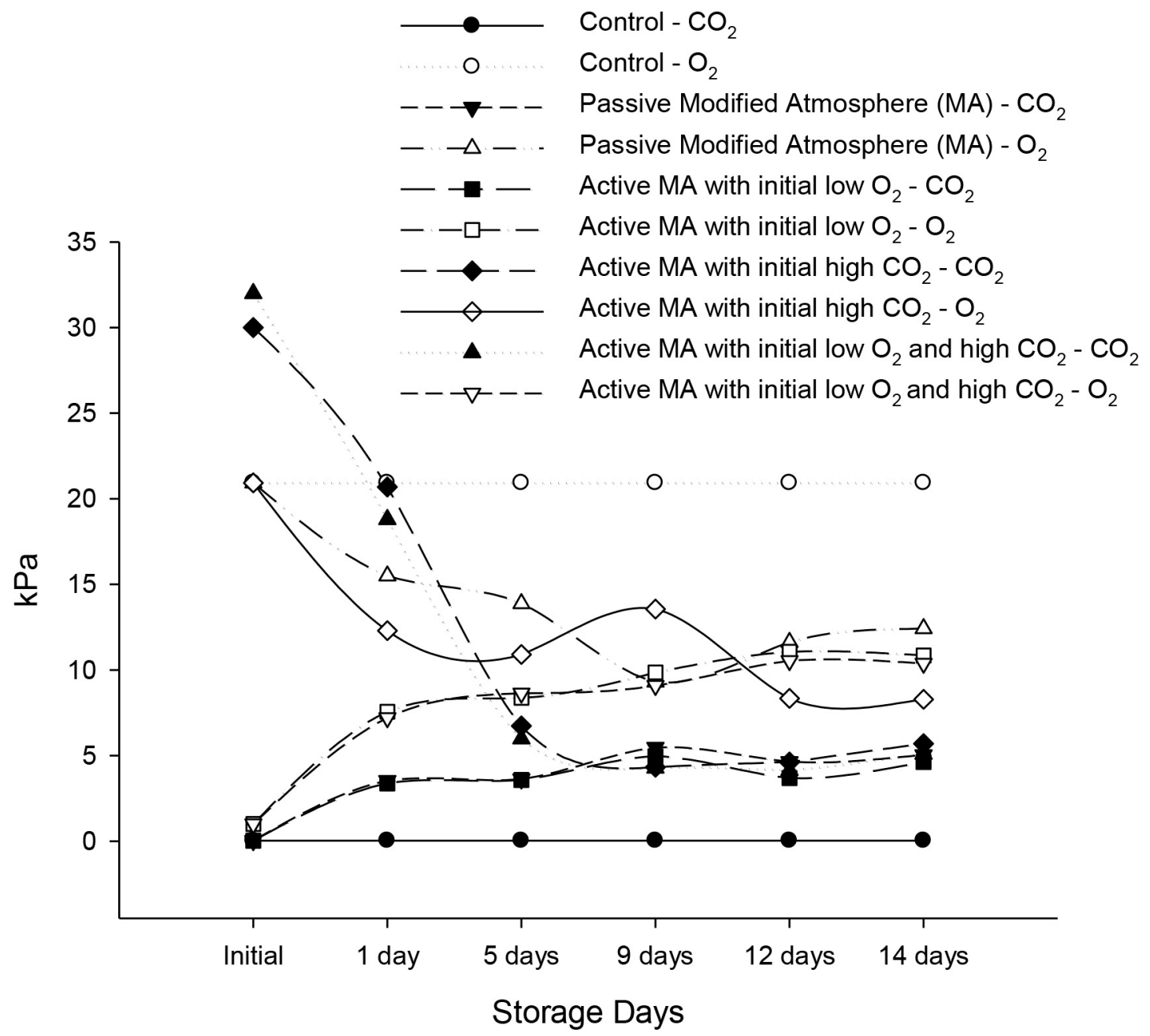

Figure 1. Partial pressures of $\mathrm{O}_{2}$ and $\mathrm{CO}_{2}(\mathrm{kPa})$ in different modified atmosphere conditions of 'San Andreas' strawberry harvested at two ripening stages (" $1 / 3$ ripe" and " $3 / 4$ ripe") during 14 days of cold storage $\left(0.5 \pm 0.2{ }^{\circ} \mathrm{C} / 92 \pm 2 \% \mathrm{RH}\right)$. Fruit of both ripening stages were stored in the same condition (MA packaging). 
Strawberries have a high respiratory rate, but there is a slow change in the atmosphere of passive MA throughout the consumption of $\mathrm{O}_{2}$ and production of $\mathrm{CO}_{2}$ by fruit, as a result of film high permeability to the gases in the packaging. Therefore, the partial pressure of $\mathrm{O}_{2}$ might not decrease and partial pressure of $\mathrm{CO}_{2}$ may not increase to the values required to preserve fruit quality. However, in active AM, low initial partial pressures of $\mathrm{O}_{2}$ and/or high initial partial pressures of $\mathrm{CO}_{2}$ act from the beginning of storage on fruit metabolism preserving fruit quality.

SSC and SSC/TA ratio were not different between treatments of MA. However, these variables were lower in fruit harvested " $3 / 4$ ripe" (data not shown). TA and skin color attributes $\left(L, C\right.$ and $\left.h^{\circ}\right)$ were not different between harvesting stages and storage conditions (data not shown). Values of skin and flesh textures were higher in fruit harvested " $1 / 3$ ripe", but this attributes were not affected by MA conditions (data not shown).
The control had the highest loss of fruit weight, without a difference between the MA conditions (Figure 2). This result shows the effectiveness of LDPE film as barrier to water vapor, therefore increasing the water vapor pressure inside the packaging and reducing fruit water loss. Similar results were reported by Kahramanoğlu (2019). According to the author, MA reduces fruit mass loss by reducing fruit respiration and transpiration. The loss of fruit weight was not affected by harvesting stage (Figure 2). However, even in the control, the loss of fruit weight was low. According to García et al. (1998), strawberries loss marketing value when the loss of weight is higher than $6 \%$. According to Kader (2002), the loss of fruit weight is the main cause of qualitative deterioration, depreciating the appeal (causing wilting and shrivel), texture (causing softening and loss of turgor and succulence) and nutritional quality, besides the direct quantitative loss.

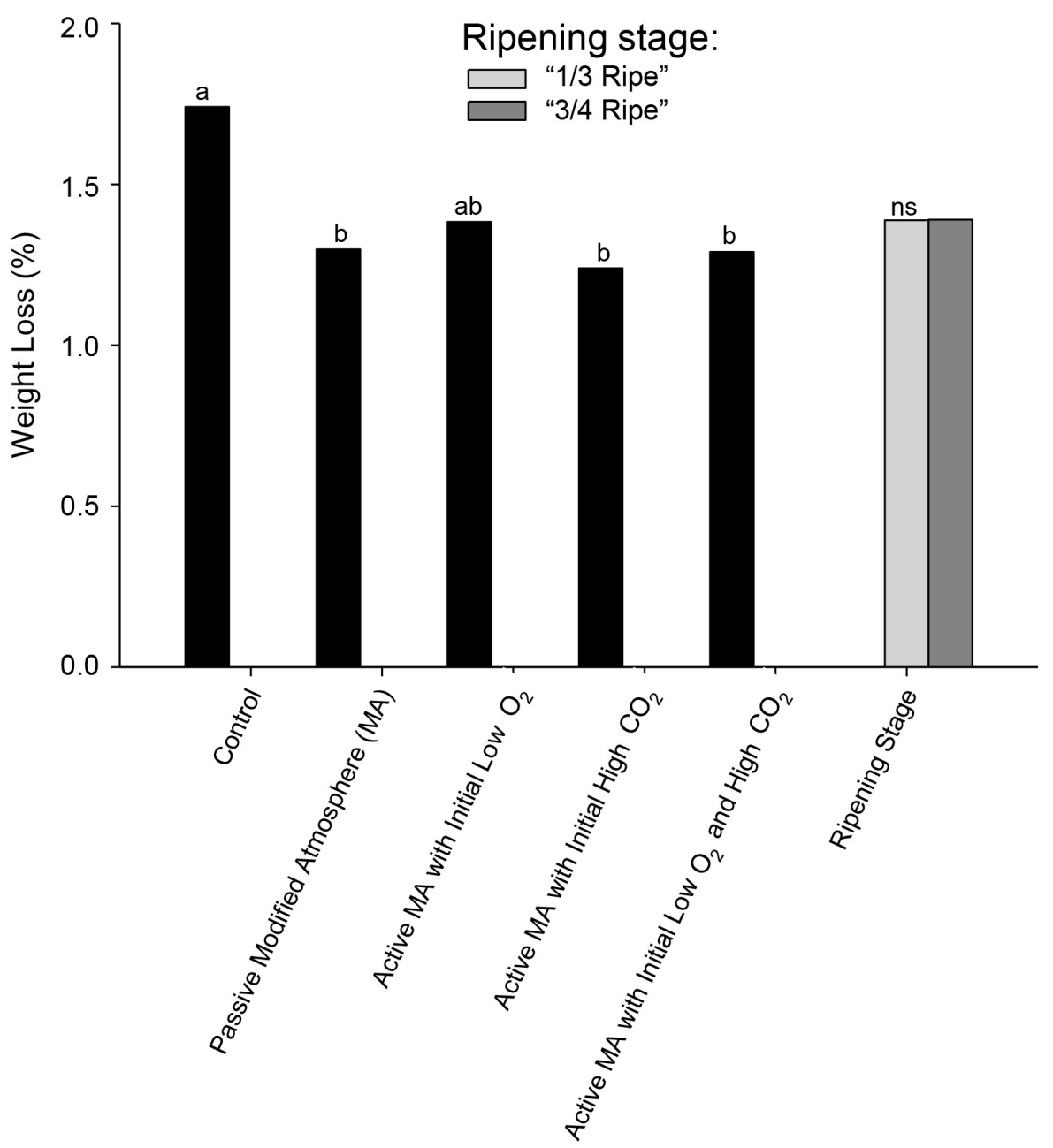

Figure 2. Weight loss (\%) of 'San Andreas' strawberry harvested at two ripening stages (" $1 / 3$ ripe" and " $3 / 4$ ripe") and stored for 14 days under refrigeration $\left(0.5 \pm 0.2^{\circ} \mathrm{C} / 92 \pm 2 \% \mathrm{RH}\right)$ in different modified atmospheres (MA), followed by two days of shelf life $\left(20 \pm 5{ }^{\circ} \mathrm{C} / 65 \pm 10 \% \mathrm{RH}\right)$. Ripening stages: " $1 / 3$ ripe" $=30 \%$ of red color; " $3 / 4$ ripe" $=75 \%$ of red color. Bars followed by the same letter are not different by Tukey's test $(\mathrm{p}<0.05)$. ns $=$ not significant. 
Fruit harvested " $1 / 3$ ripe" had the lowest incidence and severity of decay after 14 days of storage followed by two days of shelf life (Figures 3 and 4). This might reflect the higher flesh firmness of fruit harvested at less advanced ripening stage, since ripening reduce flesh firmness and makes fruit more susceptible to fungal infection (CIA et al., 2010).

Between the MA conditions, MA with high initial $\mathrm{CO}_{2}$ had the lowest incidence of decay, but being significantly different only from active MA with low initial $\mathrm{O}_{2}$ (Figure 3). The severity of decay was lowest in fruit in active $\mathrm{AM}$ with high initial $\mathrm{CO}_{2}$, and highest in the control
(Figure 4). According to Júnior et al. (2012), active MA with initial high $\mathrm{CO}_{2}(40 \mathrm{kPa})$ was effective to preserve the quality of 'Oso Grande' strawberry stored at $10{ }^{\circ} \mathrm{C}$, preserving the commercial quality and reducing the incidence of decay. Bang et al. (2018) reported in 'Seolhyang' strawberry exposed to $30 \mathrm{kPa}$ of $\mathrm{CO}_{2}$ for short duration reduced incidence of gray mold. According to the authors, the reduced deterioration and better preservation of fruit quality under MA with initial high $\mathrm{CO}_{2}$ is due to cellular response in the fruit induced by the treatment with $\mathrm{CO}_{2}$ or to the direct effect of $\mathrm{CO}_{2}$ on mycelia growth and spore germination of the pathogen.

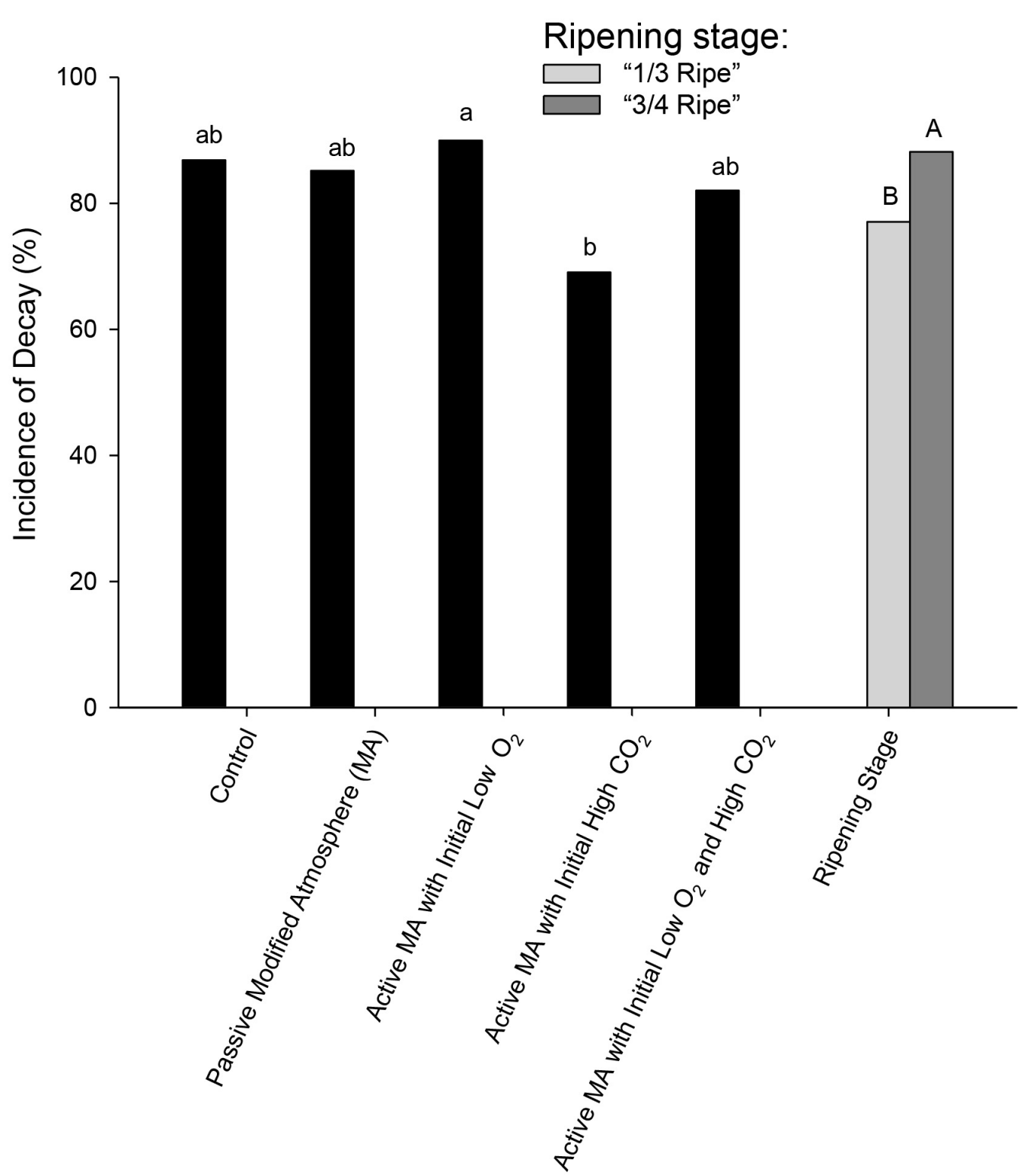

Figure 3. Incidence of decay (\%) in 'San Andreas' strawberry harvested at two ripening stages (" $1 / 3$ ripe" and " $3 / 4$ ripe") and stored for 14 days under refrigeration $\left(0.5 \pm 0.2{ }^{\circ} \mathrm{C} / 92 \pm 2 \% \mathrm{RH}\right)$ in different modified atmospheres (MA), followed by two days of shelf life $\left(20 \pm 5^{\circ} \mathrm{C} / 65 \pm 10 \% \mathrm{RH}\right)$. Ripening stages: " $1 / 3$ ripe" $=30 \%$ of red color; " $3 / 4$ ripe" $=75 \%$ of red color. Bars followed by the same letter are not different by Tukey's test $(\mathrm{p}<0.05)$. ns $=$ not significant. 


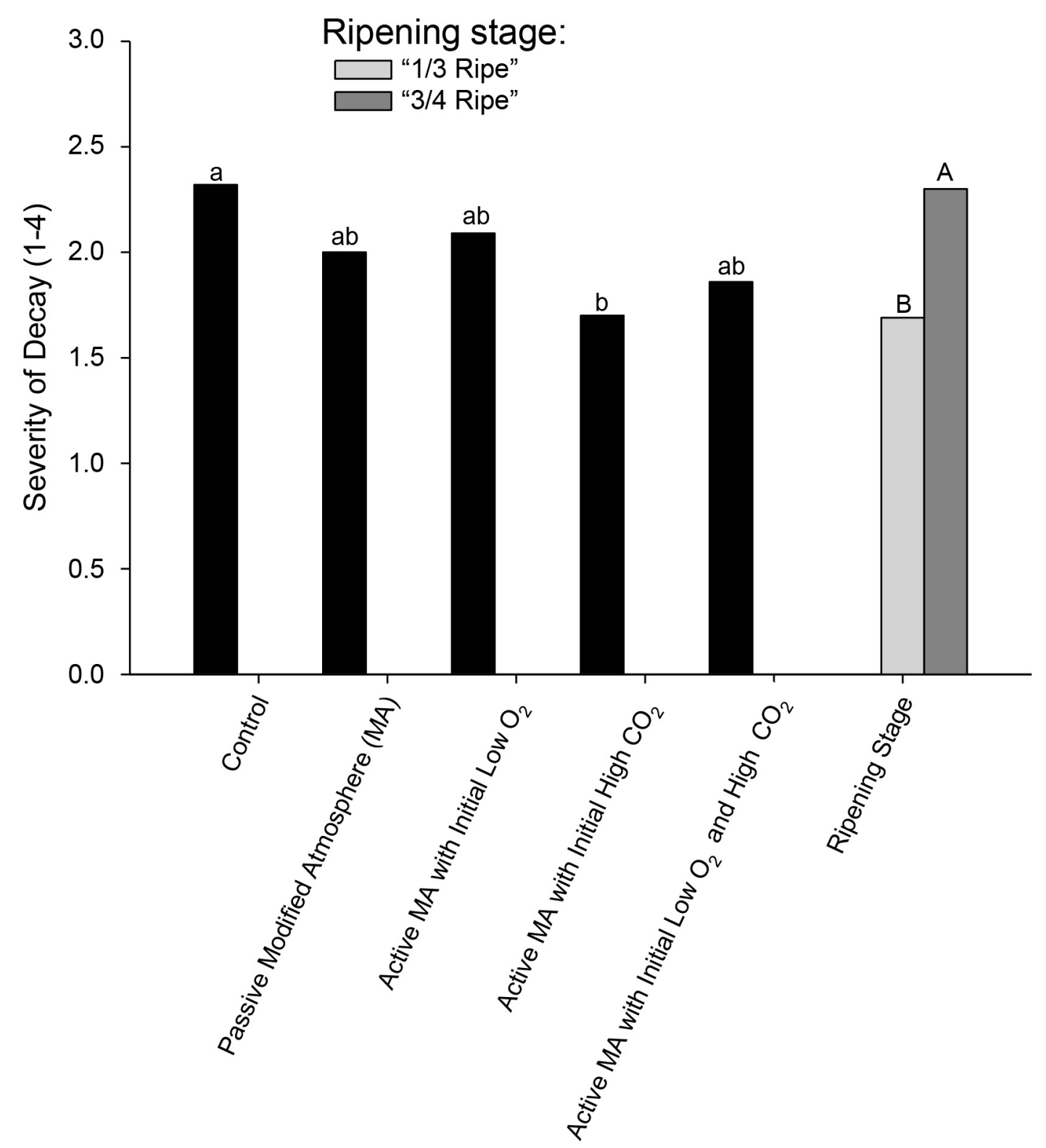

Figure 4. Severity of decay (\%) in 'San Andreas' strawberry harvested at two ripening stages (" $1 / 3$ ripe" and " $3 / 4$ ripe") and stored for 14 days under refrigeration $\left(0.5 \pm 0.2{ }^{\circ} \mathrm{C} / 92 \pm 2 \% \mathrm{RH}\right)$ in different modified atmospheres (MA), followed by two days of shelf life $\left(20 \pm 5^{\circ} \mathrm{C} / 65 \pm 10 \% \mathrm{RH}\right)$. Ripening stages: " $1 / 3$ ripe" $=30 \%$ of red color; " $3 / 4$ ripe" $=75 \%$ of red color. Bars followed by the same letter are not different by Tukey's test $(\mathrm{p}<0.05)$. ns $=$ not significant.

TPC was not different between MA conditions, but it was higher in fruit harvested " $1 / 3$ ripe" (Table 1 ). Similarly, in 'Oso Grande' strawberry TPC was higher in fruit harvested less ripe (PINELI, 2009). In plants, phenolic compounds are structural components and pigments, besides their antioxidant, antimicrobial and antiviral action. The stress caused in the fruit by temperature and changes in partial pressures of gases during storage might activate secondary metabolism of cells and the production of phenolic compounds (JIN et al., 2011). Blanch et al. (2012) reported the increase of beneficial compounds in strawberry exposed to high $\mathrm{CO}_{2}(20 \mathrm{kPa})$ for three days, such as catechin and proanthocyanidins. Genotype and environmental conditions, as well as differences related to the extraction and analysis methods used in the different studies should be considered, since these might affect variables response to the treatments. 
Table 1. Total phenolic content (TPC; mg GAE. $100 \mathrm{~g}^{-1} \mathrm{fw}$ ) and total antioxidant activity (TAA; quantified by DPPH and ABTS methods, in $\mu \mathrm{g}$ of Trolox equivalent. $\mathrm{g}^{-1} \mathrm{fw}$ ) in 'San Andreas' strawberries harvested at two ripening stages and stored for 14 days under refrigeration $\left(0.5 \pm 0.2{ }^{\circ} \mathrm{C} / 92 \pm 2 \% \mathrm{RH}\right)$ in different modified atmospheres (MA), followed by two days of shelf life $\left(20 \pm 5^{\circ} \mathrm{C} / 65 \pm 10 \% \mathrm{RH}\right)$.

\begin{tabular}{|c|c|c|c|}
\hline \multirow{3}{*}{ Treatment } & \multicolumn{3}{|c|}{ Ripening stage } \\
\hline & " $1 / 3$ ripe" & "3/4 ripe" & Mean \\
\hline & \multicolumn{3}{|c|}{ TPC } \\
\hline Control (without MA) & 49.4 & 43.4 & $46.4 \mathrm{a}$ \\
\hline Passive MA & 44.8 & 45.2 & $45.0 \mathrm{a}$ \\
\hline Active MA with initial low $\mathrm{O}_{2}$ & 45.4 & 44.2 & $44.8 \mathrm{a}$ \\
\hline Active MA with initial high $\mathrm{CO}_{2}$ & 49.2 & 42.4 & $45.8 \mathrm{a}$ \\
\hline Active MA with initial low $\mathrm{O}_{2}$ and high $\mathrm{CO}_{2}$ & 49.8 & 42.1 & $45.9 \mathrm{a}$ \\
\hline Mean & $47.7 \mathrm{~A}$ & $43.4 \mathrm{~B}$ & \\
\hline \multirow[t]{2}{*}{ CV $(\%)$} & 7.8 & 7.6 & \\
\hline & \multicolumn{2}{|c|}{ TAA - DPPH } & \\
\hline Control (without MA) & $2291.0 \mathrm{Aab}$ & $1762.7 \mathrm{Bb}$ & 2026.8 \\
\hline Passive MA & $2359.3 \mathrm{Aab}$ & $2006.0 \mathrm{Bab}$ & 2207.9 \\
\hline Active MA with initial low $\mathrm{O}_{2}$ & $2086.0 \mathrm{Ab}$ & $1819.3 \mathrm{Ab}$ & 1933.6 \\
\hline Active MA with initial high $\mathrm{CO}_{2}$ & $2712.6 \mathrm{Aa}$ & $2243.5 \mathrm{Aa}$ & 2478.1 \\
\hline Active MA with initial low $\mathrm{O}_{2}$ and high $\mathrm{CO}_{2}$ & $2736.0 \mathrm{Aa}$ & $1700.4 \mathrm{Bb}$ & 2292.2 \\
\hline Mean & 2455.5 & 1912.3 & \\
\hline \multirow[t]{2}{*}{ CV $(\%)$} & 13.26 & 13.4 & \\
\hline & \multicolumn{2}{|c|}{ TAA - ABTS } & \\
\hline$\overline{\text { Control (without MA) }}$ & 2594.4 & 1412.5 & $2003.5 \mathrm{ab}$ \\
\hline Passive MA & 2322.2 & 1600.0 & $2012.7 \mathrm{ab}$ \\
\hline Active MA with initial low $\mathrm{O}_{2}$ & 2940.7 & 1194.4 & $1942.9 \mathrm{ab}$ \\
\hline Active MA with initial high $\mathrm{CO}_{2}$ & 2669.4 & 2038.9 & $2399.2 \mathrm{a}$ \\
\hline Active MA with initial low $\mathrm{O}_{2}$ and high $\mathrm{CO}_{2}$ & 2161.1 & 988.9 & $1658.7 \mathrm{~b}$ \\
\hline Mean & $2516.3 \mathrm{~A}$ & $1430.1 \mathrm{~B}$ & \\
\hline $\mathrm{CV}(\%)$ & 18.0 & 33.6 & \\
\hline
\end{tabular}

Means followed by the same letter (upper case within lines or lower case within columns) are not different by Tukey' test ( $\mathrm{p}<0.05$ ).

The highest values of TPC in fruit harvested " $1 / 3$ ripe" might also contributed to reduce their incidence and severity of decay (Figures 3 and 4). According to Jiao et al. (2018), chlorogenic acid induces the resistance at postharvest of peach fruit to blue mold (Penicillium expansum). Chlorogenic acid also inhibited spore germination and mycelia growth in vitro of Sclerotinia sclerotiorum, Fusarium solani, Verticillium dahliae, Botrytis cinerea and Cercospora sojina (MARTÍNEZ et al., 2017). Other authors also reported a relationship between reduced decay to the high phenolic content in the fruit. Preharvest treatment with salicylic acid (a phenolic compound) induces postharvest defense mechanisms against decay, preserves the quality, delays ripening and senescence and reduces ethylene synthesis and action (GIMÉNEZ et al., 2017).
Fruit harvested " $3 / 4$ ripe" had TAA values assessed by DPPH and ABTS methods, respectively $25 \%$ and $30 \%$ lower than fruit harvested " $1 / 3$ ripe" (Table 1 ). TAA of fruit harvested " $1 / 3$ ripe" was higher when they were stored in active MA with initial high $\mathrm{CO}_{2}$, with or without low initial $\mathrm{O}_{2}$. Fruit harvested "3/4 ripe" also had higher TAA when they were stored in active MA with initial high $\mathrm{CO}_{2}$, but without differing of passive MA (Table 1). According to Zheng et al. (2012), TPC and TAA values in the fruit are affected by maturity/ripening stage. Also, TAA in the fruit results of a variety of antioxidant compounds degraded and synthesized during the storage in response to biotic and abiotic stress (ROTILI et al., 2013). 
The acetaldehyde content in fruit harvested " $1 / 3$ ripe" was significantly higher in the control than in MA storage (passive and active) Table 2 . Fruit harvested " $3 / 4$ ripe" had significantly higher acetaldehyde content in active MA with initial low $\mathrm{O}_{2}$. In fruit harvested " $1 / 3$ ripe", the ethanol content was not different between treatments. Fruit harvested " $3 / 4$ ripe" had higher production of ethanol when stored in active MA with initial low $\mathrm{O}_{2}$. For storage in active MA with initial low $\mathrm{O}_{2}$ and high $\mathrm{CO}_{2}$, fruit harvested " $3 / 4$ ripe" had higher production of ethanol than fruit harvested " $1 / 3$ ripe". Fruits harvested " $3 / 4$ ripe" had significantly higher ethyl acetate content when stored in active MA with initial low $\mathrm{O}_{2}$. On the other hand, fruit harvested " $1 / 3$ ripe" had the highest ethyl acetate content in the control, which differed statistically only from active AM with initial high $\mathrm{CO}_{2}$. The high contents of acetaldehyde, ethanol and ethyl acetate in fruits harvested " $3 / 4$ ripe" and stored in active AM with initial low $\mathrm{O}_{2}$ is detrimental, since the accumulation of these products is indicative of fermentative metabolism and fruits infection by pathogens (ÁVILA et al., 2012), causing off flavors.

Table 2. Contents of acetaldehyde, ethanol and ethyl acetate in 'San Andreas' strawberry harvested at two ripening stages and stored for 14 days under refrigeration $\left(0.5 \pm 0.2{ }^{\circ} \mathrm{C} / 92 \pm 2 \% \mathrm{RH}\right)$ in different modified atmospheres (MA), followed by two days of shelf life $\left(20 \pm 5^{\circ} \mathrm{C} / 65 \pm 10 \% \mathrm{RH}\right)$.

\begin{tabular}{|c|c|c|c|}
\hline \multirow{3}{*}{ Treatments } & \multicolumn{3}{|c|}{ Ripening stage } \\
\hline & " $1 / 3$ ripe" & "3/4 ripe" & Mean \\
\hline & \multicolumn{3}{|c|}{ Acetaldehyde $\left(\mu \mathrm{L} \mathrm{L}^{-1}\right)$} \\
\hline Control (without MA) & $10.02 \mathrm{Aa}$ & $5.07 \mathrm{Bb}$ & 7.54 \\
\hline Passive MA & $5.62 \mathrm{Abc}$ & $5.80 \mathrm{Ab}$ & 5.71 \\
\hline Active MA with initial low $\mathrm{O}_{2}$ & $7.35 \mathrm{Bb}$ & $16.73 \mathrm{Aa}$ & 12.04 \\
\hline Active MA with initial high $\mathrm{CO}_{2}$ & $2.85 \mathrm{Ad}$ & $3.90 \mathrm{Ab}$ & 3.38 \\
\hline Active MA with initial low $\mathrm{O}_{2}$ and high $\mathrm{CO}_{2}$ & 4.84 Bcd & $8.39 \mathrm{Ab}$ & 6.61 \\
\hline Mean & 6.14 & 7.98 & \\
\hline \multirow[t]{2}{*}{ CV $(\%)$} & 43.19 & 67.31 & \\
\hline & \multicolumn{3}{|c|}{ Ethanol $\left(\mu \mathrm{L} \mathrm{L}^{-1}\right)$} \\
\hline Control (without MA) & $15.75 \mathrm{Aa}$ & $15.08 \mathrm{Ab}$ & 15.41 \\
\hline Passive MA & $15.71 \mathrm{Aa}$ & $17.92 \mathrm{Ab}$ & 16.81 \\
\hline Active MA with initial low $\mathrm{O}_{2}$ & $11.37 \mathrm{Bab}$ & $59.17 \mathrm{Aa}$ & 35.27 \\
\hline Active MA with initial high $\mathrm{CO}_{2}$ & $7.19 \mathrm{Ab}$ & $10.99 \mathrm{Ab}$ & 9.09 \\
\hline Active MA with initial low $\mathrm{O}_{2}$ and high $\mathrm{CO}_{2}$ & $7.33 \mathrm{Bb}$ & $22.37 \mathrm{Ab}$ & 14.85 \\
\hline Mean & 11.47 & 25.11 & \\
\hline \multirow[t]{2}{*}{ CV (\%) } & 38.40 & 82.79 & \\
\hline & \multicolumn{3}{|c|}{ Ethyl acetate $\left(\mu \mathrm{L} \mathrm{L}^{-1}\right)$} \\
\hline Control (without MA) & $1.50 \mathrm{Aa}$ & $0.89 \mathrm{Bb}$ & 1.19 \\
\hline Passive MA & $0.78 \mathrm{Aab}$ & $1.03 \mathrm{Ab}$ & 0.91 \\
\hline Active MA with initial low $\mathrm{O}_{2}$ & $1.37 \mathrm{Ba}$ & $3.46 \mathrm{Aa}$ & 2.42 \\
\hline Active MA with initial high $\mathrm{CO}_{2}$ & $0.44 \mathrm{Bb}$ & $1.17 \mathrm{Ab}$ & 0.81 \\
\hline Active MA with initial low $\mathrm{O}_{2}$ and high $\mathrm{CO}_{2}$ & $0.85 \mathrm{Aab}$ & $1.54 \mathrm{Ab}$ & 1.19 \\
\hline Mean & 0.99 & 1.62 & \\
\hline CV (\%) & 50.76 & 68.72 & \\
\hline
\end{tabular}

Means followed by the same letter (upper case within lines or lower case within columns) are not different by Tukey' test ( $\mathrm{p}<0.05$ ).

\section{Conclusions}

The total antioxidant activity was higher in fruit harvested " $1 / 3$ ripe" (with $30 \%$ of red color), and increased in fruit stored in active modified atmosphere with initial high $\mathrm{CO}_{2}$, without or with initial low $\mathrm{O}_{2}$. The total phenolic content compounds was also higher in fruit harvested " $1 / 3$ ripe".
Fruit stored in modified atmosphere with initial low $\mathrm{O}_{2}$ had higher contents of acetaldehyde, ethanol and ethyl acetate than fruit stored in modified atmosphere with initial high $\mathrm{CO}_{2}$, regardless of ripening stage at harvest.

'San Andreas' strawberry harvested " $1 / 3$ ripe" and stored in modified atmosphere with initial high $\mathrm{CO}_{2}$ have a better postharvest quality preservation, as a results of reduced fruit weight loss and decay, without increasing the metabolites of the fermentative metabolism. 


\section{References}

ÁVILA, J.M.M; TORALLES, R.P.; CANTILLANO, R.F.F.; PERALBA, M.C.R.; PIZZOLATO, T.M. Influência do sistema de produção e do armazenamento refrigerado nas características físico-químicas e no desenvolvimento de compostos voláteis em morangos. Ciência Rural, Santa Maria, v.42, p.2265-2272, 2012.

BANG, J.; LIM, S.; YI, G.; LEE, J.G.; LEE, E.J. Integrated transcriptomic-metabolomic analysis reveals cellular responses of harvested strawberry fruit subjected to short-term exposure to high levels of carbon dioxide. Postharvest Biology and Technology, Amsterdam, v.148, p.120-131, 2018.

BLANCH, M.; ALVAREZ, I.; SANCHEZ-BALLESTA, M.T.; ESCRIBANO, M.I.; MERODIO, C. Increasing catechin and procyanidin accumulation in high $\mathrm{CO}_{2}$-treated Fragaria vesca strawberries. Journal of Agricultural and Food Chemistry,Washington,v.60, p.7489-7496, 2012.

CIA, P.; BENATO, E.A.; PASCHOLATI, S.F.; OLIVEIRA GARCIA, E. Quitosana no controle pós-colheita da podridão mole em Caqui 'Rama Forte'. Bragantia, Campinas, v.69, n.3, p.745-752, 2010.

CUNHA JÚNIOR, L.C.; JACOMINO, A.P.; OGASSAVARA, F.O.; TREVISAN, M.J.; PARISI, M.C.M. Armazenamento refrigerado de morango submetido a altas concentrações de $\mathrm{CO}_{2}$. Horticultura Brasileira,Vitória da Conquista, v.30, p.688-694, 2012.

GARCÍA J.M.; MEDINA, R.J.; OLÍAS, J.M. Quality of strawberries automatically packed in different plastic films. Journal of Food Science, New York, v.63, p.10371041, 1998.

GIMÉNEZ, M.J.; SERRANO, M.; VALVERDE, J.M.; MARTÍNEZ-ROMERO, D.; CASTILLO, S.; VALERO, D.; GUILLÉN, F. Preharvest salicylic acid and acetylsalicylic acid treatments preserve quality and enhance antioxidant systems during postharvest storage of sweet cherry cultivars. Journal of the Science of Food and Agriculture, London, v.97, p.1220-1228, 2017.

JIAO, W.; LI, X.; WANG, X.; CAO, J.; JIANG, $\mathrm{W}$. Chlorogenic acid induces resistance against Penicilliumexpansum in peach fruit by activating the salicylic acid signaling pathway. Food Chemistry, London, v.260, p.274-282, 2018.
JIN, P.; WANG, S. Y.; WANG, C. Y.; ZHENG, Y. Effect of cultural system and storage temperature on antioxidant capacity and phenolic compounds in strawberries. Food Chemistry, London, v.124, p.262-270, 2011.

KADER A.A. Postharvest biology and technology: an overview. In: KADER A.A. Postharvest technology of horticultural crops. $3^{\text {th }}$ ed. Oakland: University of California, 2002. p.279-285.

KAHRAMANOĞLU, I. Effects of lemongrass oil application and modified atmosphere packaging on the postharvest life and quality of strawberry fruits. Scientia Horticulturae, Amsterdam, v. 256, p. 209, 2019.

LU, H.; WANG, K.; WANG, L.; LI, D.; YAN, J.; BAN, Z.; LOU, Z.; LI, L.; YANG, D. Effect of superatmospheric oxygen exposure on strawberry (Fragaria ananassa Duch.) volatiles, sensory and chemical attributes. Postharvest Biology and Technology, Amsterdam,v.142, p.60-71, 2018.

MARTINEZ, G.; REGENTE, M.; SANTIAGO, J.; DEL RIO, M.; PINEDO, M.; DE LA CANAL, L. Chlorogenic acid is a fungicide active against phytopathogenic fungi. Pesticide Biochemistry and Physiology, Amsterdam, v.140, p.30-35, 2017.

PINELI, L.L.O. Qualidade e potencial antioxidante in vitro de morangos in natura e submetidos a processamentos. 2009. $222 \mathrm{f}$. Tese (Doutorado em Ciências da Saúde) - Universidade de Brasília, Brasília, 2009.

ROTILI, M.C.C.; VORPAGEL, J.A.; BRAGA, G.C.; KUHN, O.J.; SALIBE, A.B. Atividade antioxidante, composição química e conservação do maracujá-amarelo embalado com filme PVC. Revista Brasileira de Fruticultura, Jaboticabal, v.35, n.4, p.942-952, 2013.

SIDDIQUI, M. W. (ed.) Preharvest modulation of postharvest fruit and vegetable quality. London: Academic Press, 2018. p.468.

SOETHE, C.; STEFFENS, C.A.; AMARANTE, C.V.T.; MARTIN, M.S.; BORTOLINI, A.J. Qualidade, compostos fenólicos e atividade antioxidante de amoras-pretas 'Tupy' e 'Guarani' armazenadas a diferentes temperaturas. Pesquisa Agropecuária Brasileira, Brasília, v.51,p.950-957, 2016. 
VAZQUEZ-HERNANDEZ, M.; NAVARRO, S.; ZHENG, H.Z.; KIM, Y.; CHUNG, S.K. A profile SANCHEZ-BALLESTA, M.T.; MERODIO, C.; of physicochemical and antioxidant changes during ESCRIBANO, M.I. Short-term high $\mathrm{CO}_{2}$ treatment fruit growth for the utilization of unripe apples. Food reduces water loss and decay by modulating defense Chemistry, London, v.131, p.106-110, 2012. proteins and organic osmolytes in Cardinal table grape after cold storage and shelf-life. Scientia Horticulturae, Amsterdam, v.234, p.27-35, 2018. 